\title{
Management Reporting and Its Use for Information Ensuring of Agriculture Organization Management
}

\author{
Klychova G.S \\ Kazan Federal University, Institute of Management, Economics and Finance, Kazan, 420008, Russia
}

Zakirova A.R.

Kazan State Agrarian University, Kazan, 420015, Russia

Mukhamedzyanov K.Z.

Kazan State Agrarian University, Kazan, 420015, Russia

Faskhutdinova M.S.

Kazan State Agrarian University, Kazan, 420015, Russia

Email:kgaukgs@mail.ru

\section{Doi:10.5901/mjss.2014.v5n24p104}

\begin{abstract}
In the article, the procedure for formation of administrative documents is determined, information flows are identified and the major primary documents and accounting records of information for management decision making are marked out, management documents are developed and proposed that allow one to quickly gather accounting data and process the information for decision making. The main source of information for management decision-making in the assessment and optimization of structural units, business processes, and other segments of agricultural organization is internal reporting
\end{abstract}

Keywords: management accounting, internal management reporting, information, report.

\section{Introduction}

The globalization of economic relations, use of modern information systems and current information processing technologies have specific requirements for provision of agricultural organization management with detailed information in the context of business processes, forms and activities segments. There is need in reflection of costs and revenues in financial and mainly management accounting, in forming the specialized reporting, creating the system of analysis and processes and activities monitoring. In IAS and RSPA in order to ensure the effectiveness of management and monitoring of economic activity, particularly close attention is paid to specification of information on various activities.

\section{Theory}

Internal management reporting is a fundamental element of the entire management structure, the most important instrument of control in agricultural enterprise management. Despite the fact that management reporting was established long time ago, until now there is no standard form of management reporting approved at the state level. Each organization develops its own form. However, despite the lack of strict regulation in development of management accounting forms, it makes sense to be guided by the regulation on Management Reporting SMA 5B "Fundamentals of reporting information for managers" [1].

In our opinion, the internal management reporting can be described as a collection of administrative documents included in schedule of workflow, containing the system of interrelated economic indicators and used to make effective, timely management decisions. Upon decision-making, crucial is period of time from receiving a report to decision-making and its implementation. Paramount value is here acquired by location and method of supplying relevant information, accessible format of management reports. Internal management reporting does not contain a standard set of common 
shapes and is strictly individual.

Internal management reporting is an integral part of the overall accountability of enterprise and is marked out on the basis of such classification attribute, as the purpose of drawing up. In most agricultural organizations there is shared responsibility of heads of various departments for various tasks, the achievement of planned results in the overall management structure. This dividing of responsibility, as a rule, has a hierarchical structure, which is conventionally divided into three levels:

- Operational (lower) level. When planning at this level, very detailed information arrives relating directly to the current time, i.e., decisions in respect of accounts receivable and payable, payroll; complaints and claims from customers (clients), works schedule (plan) performance, identification and analysis of deviations of actual results from the planned ones actually have short-term nature. In agriculture, the operational management level is presented mostly by foremen, who reflect business operations in primary documents and further apply them to their management activities;

- Tactical (middle) level studies the effectiveness of resources use to achieve better results. Decisions are made in relation to: procurement, location (store) of stocks of raw materials and finished products, sales (based on the results of analysis), cash flows forecast. The experts at this level of management include shops executives, various specialists (agronomists, engineers, zootechnicians, etc.), who use accounting information directly from the source documents and registers;

- Strategic (top) level is aimed at the long-term prospects, involves decisions making about the organization as a whole and determines the direction of development of organization in future. Decisions are made in respect to: investments in different projects; entering new markets (development of potential markets); forecasting and budgeting. In agricultural companies, top-level management, which is represented by managers and senior staff, requires systematic information in the form of such qualitative indicators as crop production, animal productivity, labor costs and so on. These parameters can be obtained either from the primary documents, accounting records, or may be designed according to special formulas. On the basis of intensive use of these indicators it is possible to make effective management decisions, to detect and timely remove deviations [3].

When setting the workflow, one must keep to the following sequence: analysis of accounting information movement; workflow schedule formation; binding to specific employees of the enterprise the responsibility for records management; preparation of reporting activities schedule; preparation of notifications to the persons responsible for workflow implementation.

For agricultural organization management it is important to chose the way of reporting information presenting, which is directly influenced by the content of information defined and provided, and methods of its acquiring and transfer, requirements of reports users, etc. The most of administrative documents are presented traditionally in tabular form on paper. But one can also use such methods as presentation on display, with colored charts and graphs, and other means of demonstration.

The frequency of reporting for management is of great importance. In agriculture, as in other industries, it depends on the time during which the information is relevant and useful to make effective management decisions. Thus, the frequency of submission of reporting information and formation of management reports in crop production is directly influenced by such factors as seasonality of production and duration of production cycle. For example, part of management information on the progress of harvest, carried out in relatively short time, should come to users in real-time, each time it changes. Of course, the most of indicators of management accounting and reporting does not require such efficiency. Thus, data on production of stock-raising products, spoilage, deviations from standards and targets, amount of products sold and their cost are usually presented on a daily or weekly basis.

One may draw conclusions about the profitability and efficiency of certain types of products, services of industrial and auxiliary production based on monthly reports. In any case, management reporting systems need to be developed with account for the needs of leaders of various levels of management in reporting they need for its presenting in the shortest time after the end of the reporting period.

In order to make effective management decisions more informative and sufficient, we consider it is necessary to include in reports the indicators of planned (standard) or similar data of past periods. A comparison with the planned values allows us to estimate its performance and identify the causes of discrepancies, which can be caused by wrong planning and inaccuracy of forecasting. The comparison of management reporting data of past periods, comparison with indicators of advanced enterprises, industry market values present significant addition to management reporting and also have a special value and practical significance.

Farm management requires accurate and up to date information about all changes taking place in presence and movement of fixed assets, intangible assets, inventories, animals for breeding and fattening, production costs and yield of 
agricultural products, etc. Using this information, officials can make reasonable and cost-effective management decisions. As is known, one of the objectives of accounting is to provide accounting information for internal users. This information is generated at the following stages of accounting process:

1. Documentation of operations is characterized by collection of information on financial activities of organization. Since the primary documents contain primarily the reporting information that may be not enough for effective management decisions making, it may be necessary to supplement the primary document or create a new managerial document.

2. Grouping and ordering of reporting information - are characterized by technical processing and systematization of reporting information based on the chart of accounts of financial and economic activities of agribusiness organizations.

3. Formation of certain forms of accounting reporting, including internal reporting of agricultural organization used in management process.

4. Application of reporting and accounting information in the analysis of financial and economic activities of agricultural organization [4].

Managerial document is the main form of information provision to managers of organization and as the primary accounting documents it must contain the obligatory entries: name of document, name of organization, indicators (their calculations or interpretation of economic sense if applicable), conclusions and recommendations, the date of compilation, names of posts responsible for the information provided, and their signatures.

There are the following stages of internal management report [6]: 1) defining the purpose of providing information for the head; 2) determination of the level of management for which the administrative document is composed; 3 ) determining the division of the organization for which the managerial document is drawn up; 4) creating a list of indicators that most fully and objectively satisfy the requirements of the head for information; 5) calculation of indicators and their inclusion into the managerial document. On the basis of the above stages of managerial document creating, we have developed formats of internal management reports for major reporting objects of agriculture organization.

\section{Results}

When making a decision on each of the processes of assets management (purchase, repair, replacement, sale, improvement, etc..), various alternative solutions arise. To make the most effective solutions of the proposed ones, calculations for each of them should be prepared. Also, when preparing estimates for management decisions, unused production capacity should be taken into account, details of which can be obtained from technical documentation for fixed assets. Typically, accounting of this information is performed by economic planning service of organization. In preparation of managerial decision one must take into account that non-used production capacities generate extra costs for their maintenance, which consequently increases the cost; in organization loss of income occurs that it could have got, if all the production facilities have been used for its intended purpose; unused production capacity provide organizations with some flexibility in decision-making on output. In this regard, taking into account the demands of efficiency, effectiveness and comparability, we have developed a management report format for agricultural enterprises, which presents the analytical table, designed in such a way as to combine several forms of managerial documents [5].

Table 1 provides a report on fixed assets, comprising administrative data on fixed assets. This document contains information about the intended and actual availability of fixed assets, useful and actual period of their operation, the amount of accumulated depreciation. Also, it includes quality characteristics, such as functional depreciation, external depreciation, performance. Functional depreciation - reducing of consumer appeal of certain properties of an object, caused by the development of new technologies in production of similar machines or equipment. Reducing the attractiveness of the object as a result of these reasons entails its impairment. When determining the functional depreciation of tractors and equipment one must be guided by the following rules:

- Machinery and equipment previously used and not in demand in the market up to $10 \%$;

- If at the time of inspection production of the equipment of estimated modification is stopped, then - from 5 to $30 \%$ and additionally up to $15 \%$, if production of spare parts is stopped for the equipment being evaluated of this model. 
Table 1. Report on fixed assets

\begin{tabular}{|c|c|c|c|c|c|c|c|c|c|}
\hline \multirow{2}{*}{$\begin{array}{c}\text { Name of Fixed } \\
\text { Assets }\end{array}$} & \multicolumn{2}{|c|}{ Actual Availability } & \multirow{2}{*}{$\begin{array}{l}\text { Actual } \\
\text { Life, } \\
\text { Years }\end{array}$} & \multirow{2}{*}{$\begin{array}{c}\text { Expected } \\
\text { Life, } \\
\text { Years }\end{array}$} & \multicolumn{2}{|c|}{ Depreciation, } & \multirow{2}{*}{$\begin{array}{c}\text { Functional } \\
\text { Wear, } \%\end{array}$} & \multirow{2}{*}{$\begin{array}{l}\text { External } \\
\text { Wear }\end{array}$} & \multirow[b]{2}{*}{ Efficiency } \\
\hline & Number & Cost, thou. Rub.. & & & $\%$ & \begin{tabular}{|c|}
$\begin{array}{c}\text { Thousand } \\
\text { Rub. }\end{array}$ \\
\end{tabular} & & & \\
\hline $\begin{array}{c}\text { Bulldozer crawler } \\
\text { tractor DT-75N } \\
\text { based } \\
\text { "Kazakhstanets" }\end{array}$ & 1 & 200 & 17 & 20 & 85 & 1133 & 10 & $\begin{array}{l}\text { No obvious } \\
\text { signs of } \\
\text { impact of } \\
\text { outer wear is } \\
\text { revealed. }\end{array}$ & $\begin{array}{l}\text { technical level } \\
\text { is low; annual } \\
\text { checkup; } \\
\text { Repair - once } \\
\text { in three years. }\end{array}$ \\
\hline
\end{tabular}

Performance of machines is defined by technical level of products, system of checkup and repairs and operating conditions.

External wear becomes apparent in the loss of cost caused by major industrial, regional, national, or global technological, socio-economic, environmental and even political shifts and changes.

As is known, one of the objectives of cost accounting is to determine the production costs for evaluation of inventories in order to create financial statements and management decisions. Such tasks of inventory accounting as control over the observance of the norms of consumption, control of correspondence of stocks to standards established by the organization, proper allocation of cost of expended in the material resources production for the objects of calculation, shall be carried out not only for the purpose of financial reporting, but also in the management of inventories.

For decision-making management the following objectives are set: organization of timely information about presence and movement of inventory; material classification conducting; materials movement control; determination of optimal level of inventory; valuation of stocks released for management decisions making; allocation of cost of material resources expended in production for the objects of calculation; analysis of variances of actual consumption of raw materials from the normative (planned) one.

To account for the inventory in agricultural organizations a number of primary documents is used: power of attorney, credit slip; act of acceptance of materials; limit fence-card and other documents. The information provided in these documents, in our opinion, would be sufficient for classification of materials and determination of optimal inventory levels. In addition, one can analyze the supply of tangible assets, for which we propose the following form of management report (Table 2).

Table 2. Report on supply of tangible assets

\begin{tabular}{|c|c|c|c|c|c|c|c|c|c|}
\hline \multirow{3}{*}{$\begin{array}{c}\text { Type of material } \\
\text { values }\end{array}$} & \multirow{3}{*}{ Suppliers } & \multirow{3}{*}{ Quality Specifications } & \multirow{3}{*}{$\begin{array}{l}\text { Price, } \\
\text { rub.. }\end{array}$} & \multicolumn{6}{|c|}{ Scope of supply } \\
\hline & & & & \multicolumn{2}{|c|}{ plan } & \multicolumn{2}{|c|}{$\begin{array}{l}\text { reporting } \\
\text { period }\end{array}$} & \multicolumn{2}{|c|}{$\begin{array}{l}\text { on accrual } \\
\text { basis }\end{array}$} \\
\hline & & & & rub. & $\%$ & rub. & $\%$ & rub. & $\%$ \\
\hline $\begin{array}{l}\text { Thermal } \\
\text { protection }\end{array}$ & $\begin{array}{c}\text { LLC } \\
\text { "Selkhozzapchasti » }\end{array}$ & $\begin{array}{l}\text { Wicker glass-optical thread, covered with } \\
\text { silicone rubber layer }\end{array}$ & 2304 & 2304 & 100 & 2304 & 100 & 6912 & 100 \\
\hline Agricultural tires & LLC "Selkhoztekhnika & $\begin{array}{c}\text { Diagonal design with all-metal frame, in } \\
\text { chamber version }\end{array}$ & 1200 & 1200 & 100 & 1200 & 100 & 6000 & 100 \\
\hline
\end{tabular}

As for inventory management, we have developed a report form (Table 3), which is based on cards of materials reporting, statements of reporting balances of inventory in storage areas, report on movement of inventory items in storage. This document is to be drawn in the form of a register of all kinds of materials and may include such factors as product name, item number, unit of measure, rate of stock, income, consumption and residue materials at the end of the reporting period. Indicators in the management report must be adjusted in accordance with inventory data.

Table 3. Report on inventories

\begin{tabular}{|c|c|c|c|c|c|c|c|c|c|c|}
\hline \multirow{2}{*}{$\begin{array}{l}\text { Material } \\
\text { Name }\end{array}$} & \multirow[b]{2}{*}{ Item No } & \multirow{2}{*}{$\begin{array}{c}\text { Unit of } \\
\text { measurement }\end{array}$} & \multirow{2}{*}{$\begin{array}{l}\text { Norm } \\
\text { stocks }\end{array}$} & \multicolumn{3}{|c|}{ income } & \multicolumn{3}{|c|}{ consumption } & \multirow[b]{2}{*}{ residue } \\
\hline & & & & $\begin{array}{c}\text { purchase } \\
\text { price }\end{array}$ & Quantity & Sum & $\begin{array}{l}\text { Price of } \\
\text { issue }\end{array}$ & Quantity & Sum & \\
\hline Autoventilator & 000000535 & Piece & 3 & 60 & 3 & 180 & 60 & 1 & 60 & 120 \\
\hline Bucket & 000000479 & piece & 30 & 95,06 & 20 & 1901,2 & 95,06 & 5 & 475,3 & 1425,9 \\
\hline
\end{tabular}


When making management decisions on output and sales, management primarily needs information about presence and movement of finished products, formed in operational report. Movement of finished products in agriculture is registered by a variety of primary documents, analytical accounting is carried out in "Statement of sales reporting of products, works and services of agricultural organizations" and in supporting documents "Register of documents for sale of finished products" and "Register of documents for sale of inventories, works and services, fixed assets and other assets". On the basis of accounting information compiled in these documents we offer to make the managerial document "Report on movement of finished products," which will display the following for each product: channels of arrival and sales of finished products, amount of contract revenue actually received in the past month and cumulatively from the beginning of the year, and deviations.

This document is, in our opinion, will help to solve a number of problems, including:

- Evaluation of finished products. As is known, the evaluation of finished products in agriculture is conducted according to the planned (normative) production cost. There are also estimates according to accounting and market prices. According to the most researchers the most appropriate in terms of decision-making is the method of assessing according to the market cost, since in this case, management is provided with the most realistic picture on reflection of finished products in the assets of organization;

- Coordination of production with the work of provision service, namely, a change in the product range due to the customer's needs;

Taking part in the development of the system of discounts for regular customers and maintaining control of the system of discounts to make it contribute to the development of the enterprise in order to achieve the main objectives.

Particular attention should be given to obtaining of managerial information on production costs accounting. In the modern conditions formation of the cost of production is one of the urgent tasks in management decisions.

Upon cost accounting, the main task of managing is production costs management. The main condition for obtaining of reliable data on the cost of production of organization is clearly defined composition of production costs. The main principles of cost accounting organization are: coordination of cost accounting indications with planning indications; inclusion of all production costs of the reporting period in its cost; grouping and reflection of costs on production units, types of products, components and cost items; consistency of cost accounting objects with objects of calculation; providing separate reflection of production costs according to current regulations and deviations from them; maximum approximation of methodology and organization of cost accounting to IAS.

Cost management depends on how is estimated the cost of production (works, services). In the process of calculation, initially it is required to determine accurately the value of primary costs. In this respect it is necessary to carry out permanent monitoring of material values consumption in the course of production. Fairly reasonable calculation of costs of products (works and services) involves a series of successive accounting activities, which provide the formation of real costs for all accounting objects.

During the formation of information for management decisions on accounting for financial performance of organization one must use accounting information that is generated in the accounts of financial results and well presented in "Report on Financial Performance." Management information is generated based on the results of financial analysis performed and is included in managerial document "Report on the results of the work of the unit" (Table 4).

Also, the use in practice of principles of precaution and requirements to business operations documenting take the important part. This practice leads to the fact that the accounting records appear in a few weeks, or even months after the reporting period. In this regard, operational account of contracts and relationships with contractors, movement of material assets, receipts and payments, the feature of which is exceptional focus on management goals, as well as use of nondocumented sources of information, forecast estimates, etc are formed in divisions of organization. With simultaneous use of data of accounting and operational reporting for management accounting the problem of disparate data arises, forcing organization management to use manual or operational data, or accounting. 
Table 4. Report on the results of division activities for 20XX

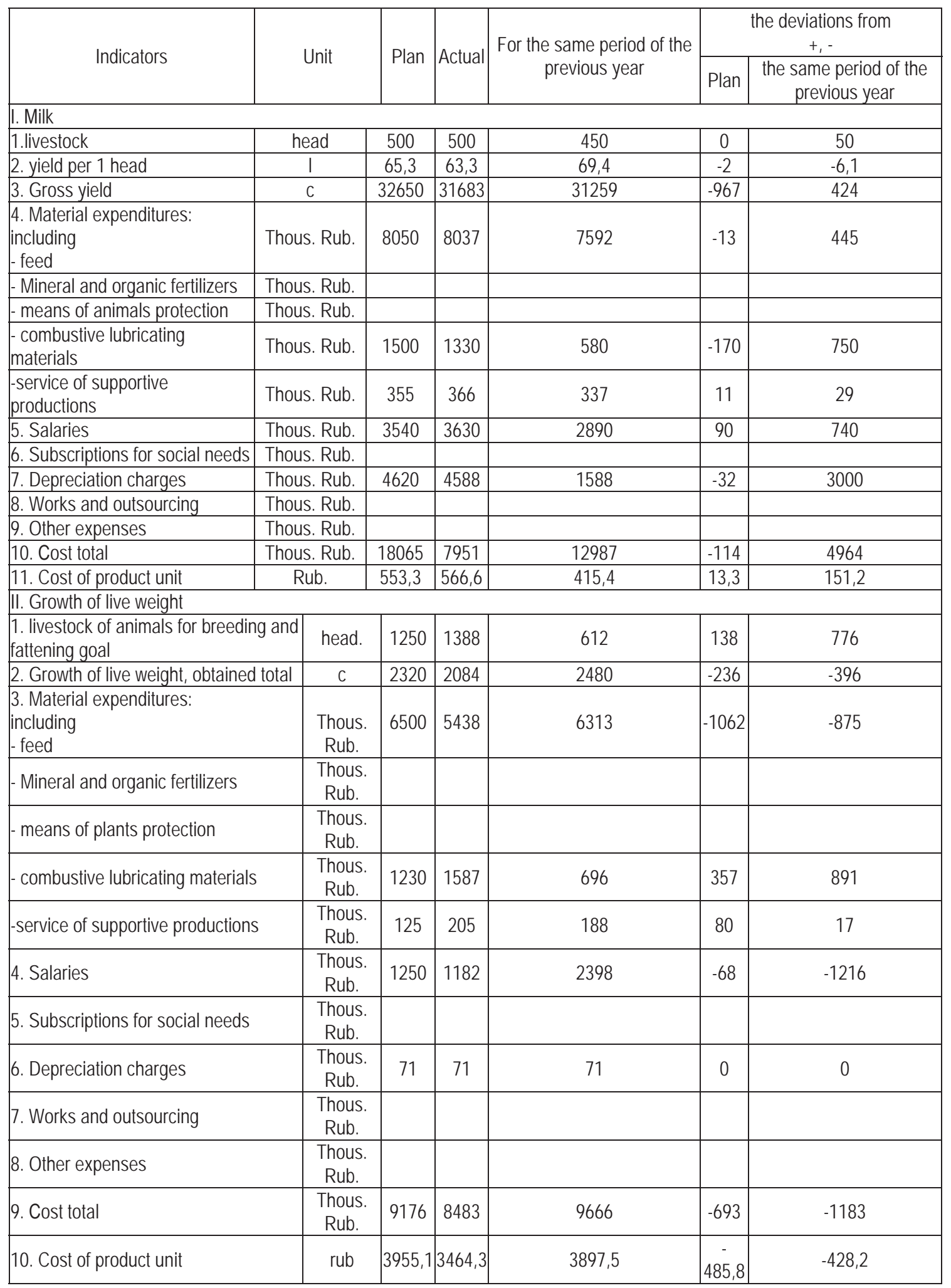

To eliminate the existing contradictions, we consider it is necessary for management accounting to use in organizations internal reporting data within a single information space of accounting information on the basis of ERP-system. In this 
system all actual data are entered once, and then they are reflected either in balance, or only in operational account, or simultaneously in both two types of accounting. Comparison of the data of sales department, procurement, finance department and other departments with the accounting data is converted into elementary automated procedure performed with any frequency on user's request.

\section{Conclusions}

Thus, we determined the order of formation of administrative documents, information flows are identified and the major source documents and accounting records of information for management decision-making are marked out, management documents are developed and proposed that allow one to quickly gather accounting data and to process the information for decision making.

Internal reporting is the main source of information for management decision-making in the assessment and optimization of structural units, business processes, and other segments of agricultural organization. Content of the internal reporting is determined by the volume of powers delegated to a particular unit. Calculation of specific indicators of reporting is largely dependent on organizational and technological features inherent in a particular organization and its structural units.

\section{References}

Averchev I.V. Management accounting and reporting. Formulation and implementation / I.V. Averchev. - M .: Vershina, 2008 - 512 p. (in Russian)

Vakhrushina M.A. Accounting Management reporting: a textbook for students enrolled on economic specialties / M.A. Vakhrushina. - 8th ed., Rev. - M .: Omega-L, 2010 - 570 p. (in Russian)

Garifullin K.M. Managerial aspects of accounting in farming: monograph / K.M.Garifullin, G.S. Klychova, A.R.Zakirova. - Kazan: Kazan.un. Press, 2003 - 248 p. (in Russian)

Klychova G.S. Management (Manufacturing) reporting in agriculture / G.S.Klychova, E.R. Sadrieva, A.R. Zakirova - Kazan: in Kazan. University Press, 2006 - 288 p. (in Russian)

Klychova G.S. Method of internal management reporting forming in Agriculture Organization [Text] / G.S. Klychova, A.R.Zakirova // Herald Kazan GAU.- 2011. - No 1 (19) .- pp. 44-48. (in Russian)

Kozmenkova S.V. Formation of accounting information in management of agricultural land market areas: monograph / S. V.Kozmenkova. - N. Novgorod, Nizhny Novgorod State Agricultural Academy, 2002 - 318 p. (in Russian)

Shirobokov V.G. Problems of formation and development of management accounting in Russia / V.G. Shirokobokov, N.N. Kosteva, L.N. Barekova // Accounting. - 2007. - No1. - pp. 62-66. (in Russian)

Scone T., 1997. Management Accounting / T. Scone, translated from Eng. Ed. N.D.Eriashvili. - M.: Audit, Unity, 179 p.

Horngren, C., 2007. Management Accounting, / Charles Horngren, G. Foster, S. Datar, trans. from English. - 10th Edition - St.: Peter, 2007. - 1008 p. (in Russian)

Balachandran, B.V. Interface between ABC / M requirements and multi-dimensional databases / BV Balachandran, K.S. Sundar / / Cost Management. - November / December. - P. 33-39.

Graham, Francis, 2000. Value-based management in practice / Francis Graham, Minchington Clare / / Management Accounting. February. - P. 46-47. 